\title{
IL-2 in combination with immune checkpoints inhibitors as a promising approach for cancer immunotherapy: A literature review
}

Relevance: Interleukin-2 (IL-2) alone has been shown to induce tumor regression and approved to treat metastatic renal cancer and melanoma. Checkpoint inhibitors realize their therapeutic effect through stimulation of immune system effectors. One of such mechanisms is the enhancement of IL-2 production by T-helpers.

The purpose of the study was to determine the effectiveness of IL-2 administration as a component of combined immunotherapy with immune checkpoint inhibitors and to suggest the mechanisms by which IL-2 can reduce the frequency and severity of side effects during checkpoint inhibitor therapy without reducing their effectiveness.

Methods: The literature search was performed in the PubMed, SCOPUS, and Web of Science databases by the keywords in article titles: "immunotherapy," "checkpoint inhibitors," "interleukin-2," and "combination therapy" for the period 2011-2021. A total of 248 relevant articles were found. The review's inclusion criteria were: clinical cases; data of clinical research methods; data on humans/body fluids from humans; literature reviews and meta-analyses. The selected 24 articles met the search criteria and were included in the study.

Results: The combined action of IL-2 and checkpoint inhibitors increases the proliferative and killer activity of the antitumor immunity effectors compared to the action of the same drugs in mono-mode at a level exceeding the summation effect.

Conclusion: The combination of IL-2 and checkpoint inhibitors can increase the effectiveness of anticancer treatment and is a promising area of immunotherapy.

Keywords: immunotherapy, checkpoint inhibitors, interleukin-2, combination therapy.

Introduction: Interleukin-2 (IL-2) is a cytokine with a molecular weight of $15.5 \mathrm{kDa}$, secreted mainly by CD4+ T-cells. Natural killer (NK), cytotoxic lymphocytes, and dendritic cells may also produce it. IL-2 is a growth and activation factor of T-cells and NKs, stimulating cytotoxic activity. Due to its functional activity, IL-2 became the first effective immunotherapy drug approved for the treatment of cancer patients [1].

High doses of IL-2 have been shown in numerous clinical studies to produce tumor regression in patients with metastatic renal cancer and melanoma, in whom standard therapy has been ineffective [2]. A dose of IL-2 of $600,000-720,000 \mathrm{IU} / \mathrm{kg}$ every 8 hours was established as the maximum tolerated dose. Under this regimen, objective regression in renal cancer patients was $23 \%$, and in melanoma patients, $29 \%$. High-dose IL-2 therapy was accompanied by significant adverse events, which in most cases were reversible $[2,3]$. One of the main problems in using IL-2 as a therapeutic antitumor drug is its ability to stimulate cytotoxic lymphocytes and T-regulatory cells, associated with immunosuppressive effects. Thus, two different strategies of IL-2 therapy have been used in clinical practice: one aimed at reducing the frequency and severity of autoimmune responses and the other at activating antitumor immunity [2]. IL-2 has been used at low doses, alone or in combination with immu- nosuppressive drugs, to activate T-regulatory cells predominantly. Presumably, a suppressive subpopulation of T-regulatory cells with a high affinity for IL-2 may more effectively compete for interaction with this cytokine at low blood levels [4]. Based on these studies, low-dose IL-2 has been tried in autoimmune diseases and conditions accompanied by immune over-activation. Several studies using low doses of IL-2 have shown an improvement in the clinical outcome of hepatitis $C$ virus-induced vasculitis and graft-versus-host disease [5]. However, attempts to reduce the frequency and severity of side-effects by lowering the dose of IL-2 have resulted in a marked loss of antitumor therapeutic effect due to the dominant impact on immunosuppressive T-regulatory cells and, consequently ${ }_{\text {,I }}$ unsatisfactory results of such treatments in cancer patients. Further studies are needed to investigate the dual effect of IL-2, as the switch of IL-2 development from T-regulatory cells to effector cells is unpredictable in clinical settings [6].

High-dose IL-2 has shown limited efficacy in studies involving kidney cancer and melanoma patients, which in the presence of severe side-effects is another severe limitation of high-dose IL-2 therapy. In addition, IL-2 has a concise duration of action when administered systemically [7]. Targeted therapy and immunotherapy with checkpoint inhibitors (ICT) have revolutionized the cur- 
rent treatment strategy for cancer patients. The discovery of monoclonal antibodies blocking immune checkpoints such as CTLA-4, PD1, and its ligand PDL1 has undoubtedly been the most critical advance in treating malignancies in the last decade. In 2011, the FDA approved ipilimumab, one of the first CTLA-4 receptor-blocking antibodies discovered, as an antitumor drug. This was followed by developing monoclonal antibodies targeting PD1 (pembrolizumab and nivolumab) and its ligand PDL1 (atezolizumab and durvalumab). ICTs are currently used as standalone drugs or combined with chemotherapy as first- or second-line treatment for around 50 types of malignancy (8). However, clinical studies show that more than half of cancer patients do not respond to ICT therapy. Severe adverse events due to nonspecific effects of ICT have been reported in some cases. The explosion of interest in IL-2 results from searching for new, highly active combinations of immuno-oncology drugs. One promising direction is the creation of new variants of IL-2-based medications. In particular, excellent clinical prospects are associated with the new pegylated IL-2 Bempegaldesleukin (NKTR-214), which, according to the developers, does not interact with the suppressor subpopulation of T-regulatory cells $[8,9]$.

The purpose of the study was to determine the effectiveness of IL-2 administration as a component of combined immunotherapy with immune checkpoint inhibitors and to suggest the mechanisms by which IL-2 can reduce the frequency and severity of side effects during checkpoint inhibitor therapy without reducing their effectiveness.

Materials and Methods: The literature search was performed in the PubMed, SCOPUS, and Web of Science databases by the keywords in article titles: "immunotherapy," "checkpoint inhibitors," "interleukin-2," and "combination therapy" for the period 2011-2021. A total of 248 articles were found in the search. Criteria for inclusion in the review: clinical cases; data from clinical study methods; data on human subjects/biofluids from humans; literature reviews and meta-analyses on the topic published in scientific peer-reviewed journals.

\section{Results:}

In total, the search revealed 248 articles: 28 articles with the keywords "interleukin-2 or IL-2 and immune checkpoints inhibitors", "interleukin-2 or IL-2 and PD-1", "interleukin-2 or IL-2 and CTLA-4", "interleukin-2 or IL-2 and PD-L1", "interleukin-2 or IL-2 and ipilimumab", "interleukin-2 or IL-2 and nivolumab", and 220 articles with the keywords "interleukin-2 or IL-2 and vaccine". Twenty-four articles meeting the search and review criteria were selected for further study.

\section{Discussion:}

The use of IL-2 in combination with vaccines

The theoretical background suggests a synergistic effect of IL-2 and antitumor vaccines in treating malignant tumors. IL-2 in combination with vaccines based on recombinant viruses, peptide antigens, or DNA vac- cines can significantly enhance the anticancer effects of the latter. A phase II study demonstrated that patients with metastatic melanoma who received high doses of IL-2 in combination with the gp100 peptide vaccine had a higher response rate than patients who received only IL-2 or the vaccine. A phase III clinical study involving patients with metastatic melanoma found that the vaccine-IL-2 combination group showed a significant increase in overall clinical response ( $16 \%$ vs. $6 \% ; p=0.03)$, survival to disease progression (median 2.2 months vs. 1.6 months; $p=0.008$ ) and overall survival (median 17.8 months vs. 16.3 months) compared to patients treated with the peptide vaccine, $p=0.06$ ) compared to the group where IL-2 was used in a monotherapy regimen. These studies showed that the addition of cytokines could enhance the effect of vaccine therapy in patients with melanoma. They highlighted the potential of using rational combinations of immune agents to treat patients with metastatic malignant tumors [10]. In addition to peptide vaccines, the use of IL- 2 in combination with dendritic cell vaccines has also been investigated. In the study, patients with stage IV melanoma received vaccination every three months and IL-2 at a dose of 3-9 million IU/ $/ \mathrm{m}^{2} /$ day. The most common side effects experienced by patients included fever (100\%), chills (50\%), hypotension (40\%), nausea (40\%), anaemia (40\%), arthralgia/myalgia (30\%), weight gain (30\%), stomatitis (30\%) and edema (30\%). The median survival of 9 of 10 patients was 198 days, with one patient alive with no clinical symptoms of disease 12 years after the initial vaccination. In another phase Ila phase, 15 patients with stage IV melanoma were vaccinated. Patients received a dendritic cell-based vaccine every six weeks in combination with IL-2 at a dose of 3 million $\mathrm{IU} / \mathrm{m}^{2} /$ on days 1,3 , and 5 after the initial vaccination. The most common side effects in patients included erythema (33\%), fever (33\%), headache $(27 \%)$, and arthralgia/myalgia (27\%). Other common side effects included rash $(20 \%)$, pain (20\%), chills $(20 \%)$, fatigue $(20 \%)$ and nausea (20\%). The median survival of patients was 590 days. Overall, data from the studies above in patients with advanced melanoma showed an improved survival rate than conventional treatments when IL-2 was included in the treatment regimen. The side-effects encountered were directly related to the action of IL-2 but not to the administration of the vaccine. A similar vaccination strategy was used in an open-label phase I study involving 10 stage IV renal cancer patients. The median survival of 6 patients was 274 days, of whom three patients lived for more than 18 months, with one patient being alive without evidence of disease for more than two years [11].

\section{$I L-2$ in combination with targeted therapy}

The antitumor activity of monoclonal antibody-based drugs, in particular trastuzumab, is mainly due to the mechanism of antibody-dependent cytotoxicity, which is realized with the participation of NK. Administration of low doses of IL-2 increased the absolute number of circulating NK by about 10-fold and induced an increase in the 
functional activity of this subpopulation of lymphocytes against target cells of breast cancer. However, activation of the innate immune system by IL-2 has not demonstrated clinical efficacy in patients with breast cancer. Given the known data on the ability of IL-2 to stimulate the immune response, a combination of IL-2 and targeted drugs have been used in several clinical studies. The efficacy and safety of the variety of IL-2 and trastuzumab in patients with HER2-positive breast cancer included ten women who received a total of 12 courses of therapy (each period lasted seven weeks). IL-2 was administered subcutaneously at a dose of $1.75 \times 10^{6} \mathrm{IU} / \mathrm{m}^{2} /$ day for 49 days. No significant toxicity was observed, although one patient required a reduction in the amount of IL-2. Of the ten patients, there was one partial response, five disease stabilization cases, and four progression cases. Based on their findings, the authors suggested that this strategy may be helpful in patients with HER2+ metastatic breast cancer who have exhausted their antitumor treatment options [12].

Phase II study of the study involved 70 patients with advanced non-small-cell lung cancer randomized into two groups: gefitinib and gefitinib + IL-2. The gefitinib + IL-2 group had a significantly higher median overall survival than patients treated with gefitinib in monotherapy (20.1 vs. 6.9 months, $p=0.002$ ). This clinical study showed that IL-2 could enhance the efficacy of targeted drugs when administered together. A retrospective analysis of the safety and effectiveness of high-dose IL-2 therapy following treatment with tyrosine kinase inhibitors in patients with metastatic renal cancer showed that the combination of IL-2 can increase the effectiveness of targeted inhibitors [13]. However, the lack of data from randomized studies does not allow unequivocal confirmation of the efficacy of combining IL-2 with other targeted drugs [14].

IL-2 in combination with immune checkpoint inhibitors

Tumor cells can elude the immune system through several mechanisms. One of the main ones is the adaptation of immune inhibitory pathways called immune checkpoints. Immune checkpoints CTLA-4 and PD-1suppress T-cell activation, and their blockade results in enhanced antitumor immunity (15). ICT therapy is currently the main focus of immunotherapy of malignant tumors. Monoclonal antibodies implement it against Programmeddeath-1 receptor (Programmeddeath-1, PD-1), Programmed Death Receptor Ligand-1 (PD-L1), and Cytotoxic T-lymphocytes antigen-4 (CTLA-4) antigen to activate the effector function of T-cells [16]. Despite the outstanding success of ICT therapy, $50-80 \%$ of patients with various variants of malignancies do not respond to this type of immunotherapy. To date, the greatest efficacy has been achieved with the concomitant use of ipilimum$\mathrm{ab}$ and nivolumab, with a 3-year overall survival rate exceeding $60 \%$ for patients with metastatic melanoma [17, 18]. However, adverse events associated with this combination have been reported in $96.8 \%$ of patients, $58.5 \%$ of which were grade 3 and 4, resulting in forced treatment discontinuation in $24.5 \%$ of patients and one fatality. In this regard, there has recently been renewed interest in the antitumor activity of IL-2 since the use of insulinoma therapy in combination with other antitumor immunotherapies such as IL-2, antigen-specific vaccination, tumor-infiltrating lymphocytes can reduce the frequency and severity of side effects and improve the effectiveness of antitumor treatment of patients [19]. The combination of IL-2 and insulinoma therapy seems appropriate given the common mechanisms of stimulation of antitumor immunity effectors. In particular, ipilimumab has been shown to exert its therapeutic effects, including immunostimulation by enhancing the production of IL-2 by T-helpers. This mechanism is supported by experimental data showing that neutralization of IL-2 or blockade of the $\alpha$ - and $\beta$-subunits of the IL-2 receptor (CD25 and $C D 122$, respectively) levels the antitumor effects of CTLA-4 blockers in mouse models in preclinical studies. In contrast, the administration of recombinant IL-2 improves the therapeutic efficacy of CTLA-4 blockers. In 262 patients with metastatic melanoma treated with ipilimumab, baseline serum concentrations of sCD25 represented an independent indicator of overall survival, with high levels predicting resistance to therapy. Overall, these results reveal a role for IL-2 receptors and IL-2 itself in promoting the antitumor effect of CTLA-4 receptor blockade. In addition, IL-2 can suppress the development of immune-mediated adverse reactions by stimulating T-regulatory cells that constitutively express CTLA-4 [20, 21]. Thus, IL-2 may enhance antitumor reactivity against CTLA-4 targeted therapy.

In a study including 36 patients with stage IV melanoma who had not previously received anti-CTLA-4 antibodies or high-dose IL-2 therapy, an objective response of $22 \%$ of patients was observed with the combined action of CTLA-4 and high-dose IL-2 treatment. While using anti-CTLA-4 antibodies in 56 patients with metastatic melanoma, the objective response rate was $12.5 \%$ [22]. Given $7-15 \%$ cumulative regression in patients with metastatic melanoma who received IL-2, the addition of IL-2 to anti-CTLA-4 treatment combined the effects of the two drugs. The results showed that high-dose administration of IL-2 after insulinoma therapies was safe and resulted in a favorable objective response rate of $22.5 \%$ and $24 \%$ for melanoma and kidney cancer, respectively. Thus, IL-2 may synergize when administered simultaneously with PD-1 receptor blockers and its ligand PD-L1 [23, 24].

Another promising treatment option for melanoma patients is a combination of systemic and topical immunotherapy. In this combination study, melanoma patients received an intratumoral injection of IL-2 in addition to PD-1 inhibitor therapy. Of 9 patients, 6 showed complete or partial regression of tumor nodules. Immunohistochemical studies revealed a significant increase in CD4+ and CD 8+ T-cells and a higher level of PD-1 expression in the tumor metastases microenvironment [16]. Ray et al. studied intratumor administration of ipilimumab and IL-2 in 12 patients with inoperable stage III-IV mela- 
noma. Ipilimumab was administered only to tumor nodes weekly for eight weeks in the following regimen: three times a week to the same node for a fortnight, then twice a week for six weeks. Intratumor injections of ipilimumab + IL-2 were well tolerated and caused regression in most patients, both in the nodes injected with immune drugs and in the nodes not injected with intra-tumoral injections [25].

\section{Conclusion:}

Of the possible options for antitumor immune therapy involving IL-2, such as IL-2 combined with dendritic cell vaccines, IL-2 combined with targeted drugs, and IL-2 combined with ICT drugs, the latter combination seems the most promising. The effectiveness of such a combination can be explained by the synergistic effect on the cellular level of immunity. Both agents stimulate natural killer cells and cytotoxic T-lymphocytes, and insulinoma therapies also stimulate IL-2 production by T-helpers. In turn, IL-2 can reduce the frequency and extent of immune-mediated adverse effects of insulinoma therapy administration, including its impact on T-regulatory cells. At the same time, the soluble receptor for IL-2, CD25, is one of the few markers of efficacy of anti-CTLA4 therapy to date. Thus, the combination of IL-2 and insulinoma therapy is promising both in terms of therapeutic effects and in the search for predictive markers due to standard pharmacokinetics.

\section{References:}

1. Mortara L., Balza E., Bruno A., Poggi A., Orecchia P., Carnemolla B. Anti-cancer therapies employing IL-2 cytokine tumour targeting: contribution of innate, adaptive and immunosuppressive cells in the anti-tumour efficacy // Front. Immunol. - 2018. - №9. - P. 1-11. https://doi.org/10.3389/fimmu.2018.02905;

2. Choudhry H., Helmi N., Abdulaal W.H., Zeyadi M., Zamzami M.A., Wu W., Mahmoud M.M., Warsi M.K., Rasool M., Jamal M.S. Prospects of IL-2 in Cancer Immunotherapy // Biomed. Res. Int. 2018. - Vol. 6. - P. 2018. https://doi.org/10.1155/2018/9056173;

3. Rosenberg S.A. IL-2: The First Effective Immunotherapy for Human Cancer //J. Immunol. - 2014. - Vol. 192. - P. 5451-5458. https://doi.org/10.4049/jimmunol.1490019;

4. Zhao Z., Zhang X., Su L., Xu L., Zheng Y., Sun J. Fine-tuning subsets of CD4(+) T-cells by low-dosage of IL-2 and a new therapeutic strategy for autoimmune diseases //Int. Immunopharmacol. - 2018. - Vol.56. - P. 269-276. https://doi.org/10.1016/j.intimp.2018.01.042;

5. Saadoun D., Rosenzwajg M., Joly F., Six A., Carrat F., Thibault V., Sene D., Cacoub P., Klatzmann D. Regulatory T-cell responses to low-dose interleukin-2 in HCV-induced vasculitis // N. Engl. J. Med. - 2011. - Vol. 365. - P. 2067-2077. https://doi.org/10.1056/NEJMoa1105143;

6. Bluestone J.A. The Yin and Yang of interleukin-2-mediated immunotherapy // N. Engl. J. Med. - 2011. - Vol. 365.- P. 2129-2131. https://doi.org/10.1056/NEJMe1110900;

7. Tan C.S., Gilligan D., Pacey S. Treatment approaches for EGFR-inhibitor-resistant patients with non-small-cell lung cancer // Lancet Oncol. - 2015. - Vol. 16. - P. 447-459. https://doi.org/10.1016/ S1470-2045(15)00246-6;

8. Robert C. A decade of immune-checkpoint inhibitors in cancer therapy // Nat. Commun. - 2020. - Vol. 11. - P. 3801. https://doi. org/10.1038/s41467-020-17670-y;

9. Mullard A. Restoring IL-2 to its cancer immunotherapy glory // Nat Rev Drug Discov. - 2021. - Vol. 20. - P. 163-165. https://doi. org/10.1038/d41573-021-00034-6;
10. Schwartzentruber D.J., Lawson D.H., Richards J.M., Conry R.M., Miller D.m., Treisman J., Failani F., Riley L., Conlon K., Pockaj B., Kendra K.L., Wgite R.L., Gonzalez R., Kuzel T.M., Curti B., Leming P.D., Whitman E.D., Balkissoon J., Reintgen D.S., Kaufman H., Marincola F.M., Merino M.J., Rosenberg S.A., Choyke P., Vena D., Hwu P. GP100 peptide vaccine and interleukin-2 in patients with advanced melanoma // N. Engl. J. Med. - 2011. - Vol. 364. - P. 2119-2127. https:// doi.org/10.1056/NEJMoa1012863;

11. Schneble E.J., Yu X., Wagner T.E., Peoples G.E. Novel dendritic cell-based vaccination in late-stage melanoma // Hum. Vaccine. Immunother. - 2014. - T.10, Vol. 11. - P.3132-3138. https://doi. org/10.4161/hv.29110;

12. Repka T., Chiorean E.G.,tnt Gay J., Herwig K.E., Kohl V.K., Yee D., Miller J.S. Trastuzumab and interleukin-2 in HER2-positive metastatic breast cancer: a pilot study // Clin Cancer Res. - 2003. - T.9, Vol. 7. - P. 2440-2446. https://pubmed.ncbi.nlm.nih.gov/12855616/;

13. Lam E.T., Wong M.K., Agarwal N., Redman B.G., Logan T., Gao D., Flaig T.W., Lewis K., Poust J., Monk P., Jarkowski A., Sendilnathan A., Bolden M., Kuzel T.M., Olencki T. Retrospective analysis of the safety and efficacy of high-dose interleukin-2 after prior tyrosine kinase inhibitor therapy in patients with advanced renal cell carcinoma // J. Immunother. - 2014. - Vol. 37. - P. 360-365.https://doi. org/10.1097/CJI.0000000000000044;

14. Bersanelli M., Buti S., Camisa R., Brighenti M., Lazzarelli S., Mazza G., Passalacqua R. Gefitinib plus interleukin-2 in advanced non-small cell lung cancer patients previously treated with chemotherapy // Cancers (Basel). - 2014. - Vol. 6. - P. 2035-2048. https:// doi.org/10.3390/cancers6042035;

15. Adachi K., Tamada K. Immune checkpoint blockade opens an avenue of cancer immunotherapy with a potent clinical efficacy // Cancer Sci. - 2015. -Vol. 106. - P. 945-950. https://doi.org/10.1111/cas.12695;

16. Majidpoor J., Mortezaee K. Interleukin-2 therapy of cancerclinical perspectives // Int. Immunopharmacol. - 2021. - Vol. 98. - P. 107836. https://doi.org/10.1016/j.intimp.2021.107836;

17. Bermudez M.V., Papa S. Setting the scene-a future 'epidemic' of immune-related adverse events in association with checkpoint inhibitor therapy // Rheumatology (Oxford). - 2019. - Vol. 58. - P. 1-6. https://doi.org/10.1093/rheumatology/kez402;

18. Xing P., Zhang F., Wang G., Xu Y., Li C., Wang S., Guo Y., Cai S., Wang Y., Li J., Incidence rates of immune-related adverse events and their correlation with response in advanced solid tumours treated with NIVO or NIVO+IPI: a systematic review and meta-analysis // J. Immuno. Thera. Cancer. - 2019. - Vol. 7. - P. 341. https:// doi.org/10.1186/s40425-019-0779-6. Correction: http://dx.doi. org/10.1136/jitc-2020-0779-6corr1;

19. Kleef R., Nagy R., Baierl A., Bacher V., Bojar H., McKee D.L., Moss R., Thoennissen N.H., Szasz M., Bakacs T. Low-dose ipilimumab plus nivolumab combined with IL-2 and hyperthermia in cancer patients with advanced disease: exploratory findings of a case series of 131 stage IV cancers - a retrospective study of a single institution // Cancer Immunol. Immunother. - 2021. - T.70, Vol. 5. - P. 1393-1403. https://doi.org/10.1007/s00262-020-02751-0;

20. Jiang T., Zhou C., Ren S. Role of IL-2 in cancer immunotherapy//Oncoimmunology. - 2016. - T.5, Vol. 6. - e1163462. https://doi. org/10.1080/2162402X.2016.1163462;

21. Hannani D., Vetizou M., Enot D., Rusakiewicz S., Chaput N., Klatzmann D., Desbois M., Jacquelot N., Vimond N., Chouaib S., Mateus C., Allison J.P., Ribas A., Wolchok H.D., Yuan J., Wong P., Postow M., Mackiewicz A., Mackiewicz J. SchadendorffD., Jaeger D., Korman A.J., Bahjat K., Maio M., Calabro L., Teng M.W.L., Smyth M.J., Eggermont A., Robert C., Kroemer G., Zitvogel L. Anticancer immunotherapy by CTLA-4 blockade: obligatory contribution of IL-2 receptors and negative prognostic impact of soluble CD25 //Cell Res. - 2015. - Vol. 25. -P. 208-224.https://doi.org/10.1038/cr.2015.3;

22. Motofei I.G. Melanoma and autoimmunity: spontaneous regressions as a possible model for new therapeutic approaches // Melanoma Res. - 2019. - T.29, Vol. 3. - P. 231-236. https://doi. org/10.1097/CMR.0000000000000573; 
23. Clark J.I., Curti B., Davis E.J., Kaufman H., Amin A., Alva A., Logan T.F., Hauke R., Miletello G.P., Vaishampayan U., Johnson D.B., White R.L., Wiernik P.H., Dutcher J.P. Long-term progression-free survival of patients with metastatic melanoma or renal cell carcinoma following high-dose interleukin-2 // J. Investig. Med. - 2021. - T.69, Vol. 4. - P. 888-892. https://doi.org/10.1136/ jim-2020-001650;

24. Shamsabadi D.R., Lehr S., von Bubnof D., Meiss F. Successful combination therapy of systemic checkpoint inhibitors and intralesional interleukin 2 in patients with metastatic melanoma with pri- mary therapeutic resistance to checkpoint inhibitors alone // Cancer Immunol. Immunother. - 2019. -Vol. 68 (9). - P. 1417-1428. https:// doi.org/10.1007/s00262-019-02377-x;

25. Ray A., Williams M.A., Meek S.M., Bowen R.C., Grossmann K.F., Andtbacka R.H.I., Bowles T.L., Hyngstrom J.R., Leachman S.A., Grossman D., Bowen G.M., Holmen S.L., VanBrocklin M.W., Suneja G., Knong H.T. A phase I study of intratumoral ipilimumab and interleukin-2 in patients with advanced melanoma // Oncotarget. - 2016. - Vol. 27, №7(39). - P. 64390-64399.https://doi.org/10.18632/oncotarget.10453.

\section{ТҰЖЫРЫМ}

\section{М.В. Киселевский ${ }^{1}$, С.М. Ситдикова ${ }^{1}$, А.А. Петкевич ${ }^{1}$}

1ФМБМ «Н.Н. Блохин атындағы онкология Ұлттық медициналық зерттеу орталығы», Мәскеу, Ресей Федерациясы

\section{Интерлейкин-2 иммундық бақылау нүктелерінің тежегіштерімен біріктірілген иммунотерапияның болашағы: Әдебиетке шолу}

Өзектілігі: Интерлейкин-2 (ИЛ-2) монотерапия режимінде ісік тің регрессиясын тудыруы мүмкін екенін көрсетті және метастатикалық бүйрек қатерлі ісігі мен меланоманы емдеуге мақұлданды. Бақылау нүктелерінің (aкm) тежегіштері өздерінің емдік әсерін иммуностимуляция арқылы іске асырады, оның тетіктерінің бірі ИЛ-2 m-хелперлермен өнімдерді күшейту болып табылады.

Мақсаты: жарияланған деректер негізінде ИЛ-2 иммундық бақылау нүктелерінің тежегіштерімен біріктірілген иммунотерапияның құрамдас бөлігі ретінде қолдану мүмкіндігін бағалау және ИЛ-2 акт емдеу кезінде жанама әсерлердің жиілігі мен айқындылығын соңғысының тиімділігін төмендетпей төмендетуі мүмкін механизмдерді болжау.

Әдістері: дереккөздерді іздеу «Иммунотерапия», «Бақылау нүктелерінің ингибиторлары», «Интерлейкин-2», «Аралас терапия» мақалаларындағы негізгі сөздер бойынша 2011-2021 жылдардағы PubMed, SCOPUS және Web of Science мәліметтер базасы бойынша жүргізілді. Іздеу бойынша барлығы 248 мақала табылды. Зерттеуді шолуға қосу критерийлері: клиникалық жағдайлар; зерттеудің клиникалық әдістерінің деректері; адамдардың/биологиялық сұйықтықтардың деректері; ғылыми рецензияланатын журналдарда жарияланған тақырып бойынша әдеби шолулар мен мета-талдаулар. Барлығы шолуға қосу критерийлеріне сәйкес келетін 24 мақала енгізілді.

Нәтижелері: ИЛ-2 және АКТ аралас әсері осы препараттардың монорежимдегі қосындылау әсерінен асатын деңгейдегі әсерімен салыстырғанда ісікке қарсы иммунитет әсерлерінің пролиферативті және киллерлік белсенділігін күшейту үшін жүргізіледі.

Қорытынды: ИЛ-2 және АКТ препараттарының үйлесуі ісікке қарсы емнің тиімділігін арттыруы мүмкін және иммунотерапияның перспективалы бағыты болып табылады.

Түйінді сөздер: иммунотерапия, бақылау нүктелерінің ингибиторлары, интерлейкин-2, аралас терапия.

\section{АННОТАЦИЯ}

\author{
М.В. Киселевский ${ }^{1}$ С.М. Ситдикова ${ }^{1}$, А.А. Петкевич ${ }^{1}$
}

1ФГБУ «Национальный медицинский исследовательский центр онкологии им. Н.Н. Блохина», Москва, Российская Федерация

\section{Перспективы комбинированной иммунотерапии Интерлейкином-2 с ингибиторами иммунных контрольных точек: Обзор литературы}

Актуальность: Интерлейкин-2 (ИЛ-2) в режиме монотерапии продемонстрировал способность вызывать регрессию опухоли и был одобрен для лечения метастатического рака почки и меланомы. Ингибиторы контрольных точек (ИКТ) реализуют свое терапевтическое действие посредством иммуностимуляции, одним из механизмов которой является усиление продукции ИЛ-2 Т-хелперами.

Цель: Оченить, на основании опубликованных данных, возможности применения ИЛ-2 в качестве компонента комбинированной иммунотерапии с ингибиторами иммунных контрольных точек и предположить механизмы, за счёт которых ИЛ-2 может снижать частоту и выраженность побочных эффектов при терапии ИКТ не снижая эффективность последних.

Методы: Поиск источников осуществлялся по базам данных PubMed, SCOPUS u Web of Science за 2011-2021 годы по ключевым словам в заголовках статей: "иммунотерапия", "ингибиторы контрольных точек", "интерлейкин-2", "комбинированная терапия". Всего по поиску найдено 248 статей. Критерии включения исследования в обзор: кли нические случаи; данные клинических методов исследования; данные на людях / биологических жидкостях от людей; литературные обзоры и метаанализы по теме, опубликованные в научных рецензируемых журналах. Всего в обзор было включено 24 статьи, отвечавших критериям включения.

Результаты: Комбинированное действие ИЛ-2 и ИКТ проводит к усилению пролиферативной и киллерной активности эффекторов противоопухолевого иммунитета, по сравнению с действием этих же препаратов в монорежиме на уровне, превышающем эффект суммации.

Заключение: Комбинация препаратов ИЛ-2 и ИКТ может повысить эффективность противоопухолевого лечения и является перспективным направлением иммунотерапии.

Ключевые слова: иммунотерапия, ингибиторы контрольных точек, интерлейкин-2, комбинированная терапия.

Transparency of Research - Authors are responsible for the content of this article.

Conflict of interests: Authors declare that there is no conflict of interest.

Authors' contributions: contribution to the study concept - Kiselevsky M.V.; study design - Kiselevsky M.V.jexecution of the study - Kiselevsky M.V. Sitdikova S.M., Petkevich A.A.; interpretation of the study - Kiselevsky M.V., Sitdikova S.M.; preparation of the manuscript - Kiselevsky M.V., Sitdikova S.M., Petkevich A.A.

Authors' data:

Kiselevsky Mikhail Valentinovich - Doctor of Medicine, Professor, Head of Cell immunity Laboratory of FGBU "N.N. Blokhin National Medical Research Center of Oncology," Ministry of Health of Russian Federation, Kashirskoye highway 23, Moscow 115478, tel. +7 903 199 49 72, e-mail: kisele@inbox.ru.ru, ID ORCID: https://orcid.org/0000-0002-0132-167X;

Sitdikova Suriya Mansurovna - Candidate of Biology, Senior Researcher of Cell Immunity Laboratory of FGBU "N.N. Blokhin National Medical Research Center of Oncology," Ministry of Health of Russian Federation, Kashirskoye highway 23, Moscow 115478, e-mail: suriyasitdikova@yandex.ru, ID ORCID: https://orcid.org/0000-0002-2840-1186;

Petkevich Alisa Antonovna (correspondent author) - Science Lab technician in the Cell Immunity laboratory of FGBU "N.N. Blokhin National Medical Research Center of Oncology," Ministry of Health of Russian Federation, Kashirskoye highway 23, Moscow 115478, tel. +7 9199997748 , e-mail: pa.alisa26@gmail.com, ID ORCID: https://orcid.org/0000-0001-7722-9821. 